\title{
Dependence of an alkyl glycol-ether monooxygenase activity upon tetrahydropterins
}

\author{
Seymour Kaufman ${ }^{1}$, Robert J. Pollock ${ }^{1}$, George K. Summer ${ }^{1}$, Arun K. Das ${ }^{2}$ \\ and Amiya K. Hajra ${ }^{2}$ \\ ${ }^{\prime}$ Laboratory of Neurochemistry, NIMH, NIH Bethesda, MD and ${ }^{2}$ Neuroscience Laboratory, \\ Mental Health Research Institute and Department of Biological Chemistry, University of Michigan, Ann Arbor, MI (U.S.A.)
}

(Received 3 January 1990)

(Revised manuscript received 11 April 1990)

Key words: Glycol ether; Glyceryl ether; Monooxygenase; Pterin

Glyceryl-ether monooxygenase (1-alkyl-sn-glycerol,tetrahydropteridine : oxygen oxidoreductase, EC 1.14.16.5) catalyzes the oxidative cleavage of 1- $O$-alkyl glycerol or glycol derivatives to a long-chain aldehyde and the glycerol or glycol derivative. The specificity for tetrahydropterins of a similar, perhaps identical, enzyme that cleaves $O$-hexadecyl ethylene glycol in rat liver microsomes was examined with the use of an assay based on [1- $\left.{ }^{3} \mathrm{H}\right]$ ethylene glycol formation from 2-hexadecyloxy[1- $\left.{ }^{3} \mathrm{H}\right]$ ethan-1-ol. Several tetrahydropterin derivatives are effective electron donors for this reaction, and 2,4,5-triamino-6-hydroxypyrimidine is somewhat effective, but NADH, NADPH, ascorbate, reduced dichlorophenolindophenol and glutathione are inactive. Tetrahydropterin derivatives differ from each other in apparent $K_{\mathrm{m}}$ and apparent $V_{\max }$. The order of increasing apparent $K_{\mathrm{m}}$ values is tetrahydropterin $\approx 6$-methyltetrahydropterin $\approx$ tetrahydrobiopterin <6.7-dimethyltetrahydropterin < tetrahydrofolate. The order of increasing apparent $V_{\max }$ values is tetrahydrofolate $\approx$ tetrahydropterin $<6$-methyltetrahydropterin $\approx$ tetrahydrobiopterin $\approx 6,7$-dimethyltetrahydropterin. Results obtained with the use of a spectrophotometric assay, in which tetrahydropterin oxidation is coupled to NADH oxidation by dihydropteridine reductase (NAD(P)H:6,7-dihydropteridine oxidoreductase, EC 1.6.99.7), indicated that the ratio of 6,7-dimethyltetrahydropterin or 6-methyltetrahydropterin oxidized to ether lipid degraded is about 1.1 to 1.3. Unlike cytochrome $P$-450-dependent hydroxylases, this alkyl glycol-ether monooxogenase is not inhibited by carbon monoxide. 1- $O$-hexadecyl-rac-glycerol (chimyl alcohol) competitively inhibits the oxidation of the glycol ether indicating that the same enzyme probably catalyzes the oxidation of both $O$-alkyl glycol and 1-O-alkyl glycerol.

\section{Introduction}

Glyceryl-ether monooxygenase (1-alkyl-sn-glycerol,tetrahydropteridine : oxygen oxidoreductase, EC 1.14.16.5) catalyzes the oxidative cleavage of a 1-O-alkyl glycerol or glycol derivative to a long-chain aldehyde and the glycerol or glycol derivative [1]. It is a microsomal enzyme that is most active in liver but there is about one-fourth as much activity in intestine and about one-twentieth as much activity in brain [2].

Acceptable structures for the lipid substrate of glyceryl-ether monooxygenase have been largely characterized. Alkyl glycerolipids that contain acyl or phosphate groups on the glycerol portion are not substrates for glyceryl-ether monooxygenase, but the enzyme will

Correspondence: S. Kaufman, Laboratory of Neurochemistry, NIMH, NIH, Bethesda, MD 20205, U.S.A. accept 1-alkyl-sn-glycero-3-phosphoethanolamine, 1-alkyl-sn-glycero-3-phosphocholine and racemic 1-, 2- and 3-isomeric forms of alkyl glycerol [3,4]. 1-O-Alkyl glycerol or glycol containing an unbranched alkyl chain of 14 to 18 carbons are good substrates, while shortchain alkyl glycerols or 1-benzyl glycerol are not [3]. Alkyl dihydroxyacetone derivatives or isopyropylidine derivatives of $1-O$-alkyl glycerol are also not substrates $[1,5]$.

In contrast to the characterization of the lipid substrate, little work has been done to characterize the reducing agent needed for this mixed-function oxygenase, although it is thought to require a tetrahydropterin [1,6]. At a concentration of $10 \mu \mathrm{M}$, the following relative activities have been observed in the presence of the indicated tetrahydropterin derivative: tetrahydrofolate (0.1), 6,7-dimethyltetrahydropterin (0.3), 6-methyltetrahydropterin (1) and tetrahydroneopterin (2) [1]. For 6-methyltetrahydropterin, a $K_{\mathrm{m}}$ of about $100 \mu \mathrm{M}$ has been reported [6]. 
In the work reported here, we investigated the specificity of the $O$-alkyl glycerol-ether monooxygenase activity of liver for tetrahydropterins and examined what effect tetrahydropterin structure has on the reaction rate and stoichiometry. We also studied whether the same enzyme is responsible for the metabolism of both alkyl glycol and alkyl glycerol. Since tetrahydropterins are capable of non-catalytically reducing hemoproteins $[7,8]$, therefore, we tested the possibility that the major microsomal hydroxylase, the cytochrome $P$ 450-dependent hydroxylase, might be involved in this glycol-ether monooxygenase reaction.

\section{Materials and Methods}

\section{Source of chemicals}

Sodium boro $\left[{ }^{3} \mathrm{H}\right]$ hydride $(250 \mathrm{Ci} / \mathrm{mol})$ was purchased from ICN as a crystalline solid. It was dissolved in distilled, dried pyridine and stored desiccated at $4^{\circ} \mathrm{C}$. Nonradioactive sodium borohydride was purchased from Sigma Chemicals. Chimyl alcohol (3(hexadecyloxy)-1,2-propanediol) was purchased from Applied Science. Pterin derivatives were purchased from the following companies: biopterin from Regis Chemical; pterin, tetrahydrofolic acid and 6-methyltetrahydropterin from Sigma Chemicals; and 6,7-dimethyltetrahydropterin from Aldrich Chemicals. ICN was the source of 2,4,5-triamino-6-hydroxypyrimidine. Sigma was the source of 7-ethoxycoumarin and J.T. Baker Chemicals was the source of 7-hydroxycoumarin. Ovine dihydropteridine reductase (NAD(P)H : 6,7-dihydropteridine oxidoreductase, EC 1.6.99.7), alkaline phosphates from Escherichia coli and glucose-6-phosphate dehydrogenase from Leuconostoc mesenteroides (Dglucose-6-phosphate : $\mathrm{NADP}^{+}$1-oxidoreductase, EC 1.1.1.49) were purchased from Sigma Chemicals. Adult, male Sprague-Dawley rats were from Zivic-Miller or from Harlan Sprague-Dawley (Indianapolis, IN). Scintillation counting cocktail was Scintiverse from Fisher Scientific.

\section{Preparation of 2-hexadecyloxy $\left[1-{ }^{3} \mathrm{H}\right]$ ethan-1-ol}

We prepared this lipid substrate by a modification of published procedures $[9,10]$. Chimyl alcohol was dissolved at $5 \mathrm{mg} / \mathrm{ml}$ in $90 \%$ (by vol.) aq. acetic acid containing $50 \mathrm{mM}$ sodium periodate. After a $1 \mathrm{~h}$ incubation at room temperature $\left(25^{\circ} \mathrm{C}\right)$ in darkness, 1 vol. water was added and the solution was then extracted twice with 1 vol. hexane/diethyl ether $(1: 1$, $\mathrm{v} / \mathrm{v})$. The hexane/diethyl ether extract was dried under nitrogen, dissolved in 1 vol. of $100 \mathrm{mM} \mathrm{NaB}^{3} \mathrm{H}_{4}$ in absolute ethanol (spec. act., $10.8 \mathrm{Ci} / \mathrm{mol}$ ) and incubated for $1 \mathrm{~h}$ at room temperature. 1 vol. of $0.5 \mathrm{M} \mathrm{HCl}$ was added to this solution and the mixture was then extracted twice with hexane/diethyl ether $(1: 1, \mathrm{v} / \mathrm{v})$. The hexane/diethyl ether extract was dried under nitrogen and stored in ethanol at $20^{\circ} \mathrm{C}$. Nonradioactive 2hexadecyloxy-1-ethanol was prepared similarly. To prepare $10 \mathrm{mM}$ 2-hexadecyloxy[1- ${ }^{3} \mathrm{H}$ ]ethan-1-ol (spec. act. $=170 \mathrm{cpm} / \mathrm{nmol}$ ), the radioactive ether lipid was diluted with nonradioactive ether lipid, dried under nitrogen, dissolved in $95 \%$ aqueous ethanol and stored at $-20^{\circ} \mathrm{C}$.

\section{Preparation of 1-O-hexadecyl-rac- $\left[2-{ }^{3} \mathrm{H}\right]$ glycerol}

1- $O$-hexadecyl-rac- $\left[2-{ }^{3} \mathrm{H}\right]$ glycerol-3- $P$, prepared by reducing 1- $O$-hexadecyl dihydroxyacetone-3-P with $\mathrm{Nab}^{3} \mathrm{H}_{4}$ [11], was enzymatically dephosphorylated to make $\left[2-{ }^{3} \mathrm{H}\right]$ chimyl alcohol. The reaction mixture contained 1-O-hexadecyl-rac- $\left[2-{ }^{3} \mathrm{H}\right]$ glycerol-3- $P(0.8 \mathrm{mg}$, $5500 \mathrm{cpm} / \mathrm{nmol})$ in Tris- $\mathrm{HCl}$ buffer $(0.15 \mathrm{M}, \mathrm{pH} 8.5)$ and $E$. coli alkaline phosphatase $(0.1 \mathrm{mg}, 4.3 \mathrm{U})$ in a total volume of $0.6 \mathrm{ml}$. The mixture was incubated at $37^{\circ} \mathrm{C}$ for $3 \mathrm{~h}$ and the resulting $\left[2-{ }^{3} \mathrm{H}\right]$ chimyl alcohol was extracted with chloroform/methanol [12]. The product was further purified by thin-layer chromatography on silica gel using a solvent mixture of diethyl ether/methanol $(90: 10)$. The band containing chimyl alcohol $\left(R_{\mathrm{F}}=0.75\right)$ was scraped off and the powder was extracted two times with $\mathrm{CHCl}_{3}$. The overall yield of the labeled chimyl alcohol from 1- $O$-hexadecyl-rac$\left[2-{ }^{3} \mathrm{H}\right]$ glycerol-3-P was $60 \%$.

\section{Preparation of tetrahydropterins}

We reduced pterin derivatives to tetrahydropterin derivatives by a modification of published methods $[13,14] .10 \mathrm{mg}$ of platinum oxide were suspended in 1 $\mathrm{ml}$ of $1 \mathrm{M} \mathrm{HCl}$ in a Thunberg tube, the tube was evacuated and flushed with hydrogen three times, and the mixture incubated for $30 \mathrm{~min}$ at $37^{\circ} \mathrm{C} .30 \mathrm{mg}$ of pterin derivative were then added and the tube again evacuated and flushed with hydrogen three times. The mixture was stirred overnight at $42^{\circ} \mathrm{C}$ under hydrogen, and during this time the tube was evacuated and flushed with hydrogen three more times. The catalyst was allowed to settle and the supernatant solution removed under nitrogen blanket to a syringe and filtered through a Millipore filter attached to the syringe. The catalyst was washed with $1 \mathrm{ml}$ of $1 \mathrm{M} \mathrm{HCl}$ and the wash solution filtered into the original filtrate. The tetrahydropterin derivative was lyophilized and stored desiccated at $-20^{\circ} \mathrm{C}$.

\section{Preparation of microsomes}

Microsomes were prepared from rat liver by two methods. Microsomes isolated by differential centrifugation [15] were washed twice and then the pellet was resuspended in one-fifth the homogenate volume of 0.25 $\mathrm{M}$ sucrose and stored at $-20^{\circ} \mathrm{C}$ in $1 \mathrm{ml}$ aliquots (about $15 \mathrm{mg}$ protein/ml). Microsomes isolated by $\mathrm{CaCl}_{2}$ precipitation [16] were washed twice with $10 \mathrm{mM}$ Tris-HCl (pH 7.6), $150 \mathrm{mM} \mathrm{KCl}$ and resuspended in this buffer 

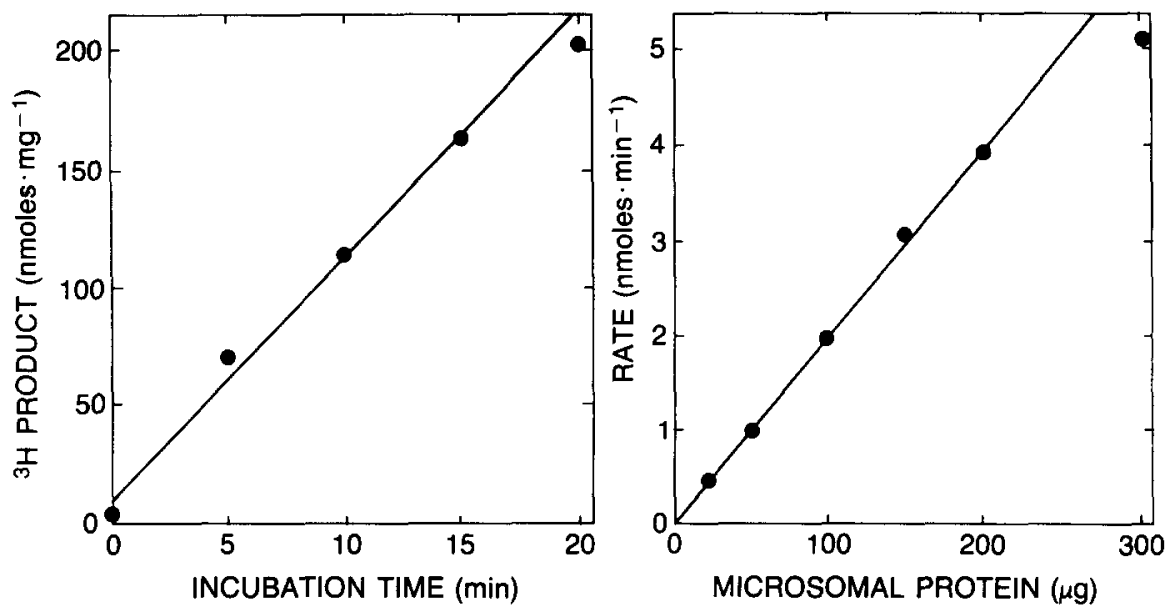

Fig. 1. Dependence of glycol-ether monooxygenase assay on incubation time and microsomal protein. The following mixtures were incubated at $37^{\circ} \mathrm{C}$ in $0.5 \mathrm{ml}$ final volume: $100 \mathrm{mM}$ potassium glycine $(\mathrm{pH} 8.8), 0.4 \mathrm{mM}$ 2-hexadecyloxy[1- $\left.{ }^{3} \mathrm{H}\right]$ ethan-1-ol $(\mathrm{spec}$. act. $=170 \mathrm{cpm} / \mathrm{nmol}), 0.2 \mathrm{mM}$ 6-methyltetrahydropterin, $10 \mathrm{mM}$ disodium glutathione, $5 \mathrm{mM}$ ammonium sulfate and $1000 \mu \mathrm{mol} / \mathrm{min}$ catalase activity per ml. Microsomal protein concentration was $0.2 \mathrm{mg} / \mathrm{ml}$ in the experiment to determine dependence of assay on incubation time. Incubation time was 15 min in the experiment to determine dependence of assay on microsomal protein. The reactions were stopped by extraction [14] of unreacted ether lipid and 1 $\mathrm{ml}$ of the aqueous phase was counted.

in one-tenth the homogenate volume and stored at $-20^{\circ} \mathrm{C}$ in $1 \mathrm{ml}$ aliquots (about $15 \mathrm{mg}$ protein $/ \mathrm{ml}$ ). Unless otherwise stated, microsomes were prepared by the first method, using differential centrifugation [15].

\section{Radiometric assay}

2-Hexadecyloxy[1- $\left.{ }^{3} \mathrm{H}\right]$ ethan-1-ol was degraded by the glycol-ether monooxygenase to $\left[1-{ }^{3} \mathrm{H}\right]$ ethylene glycol in $100 \mathrm{mM}$ potassium glycine ( $\mathrm{pH} 8.8), 0.2 \mathrm{mM}$ 6-methyltetrahydropterin, $0.4 \mathrm{mM}$ 2-hexadecyloxy $\left[1-{ }^{3} \mathrm{H}\right]$ ethan-1ol (spec. act. $=170 \mathrm{cpm} / \mathrm{nmol}$ ) added in $20 \mu 1$ 95\% ethanol, $10 \mathrm{mM}$ disodium glutathione, $5 \mathrm{mM}$ ammonium sulfate, $1000 \mu \mathrm{mol} / \mathrm{min}$ catalase activity per $\mathrm{ml}$ and $0.2 \mathrm{mg}$ microsomal protein per $\mathrm{ml}$ in a final vol. of $0.5 \mathrm{ml}$. The incubations were stopped by extracting the lipids by the method of Bligh and Dyer [12]. $1 \mathrm{ml}$ aqueous phase was counted in $10 \mathrm{ml}$ scintillation counting cocktail.

Some characteristics of this radiometric assay are shown in Table I and Figs. 1-3. Table I shows that the major radioactive product that is extracted into the aqueous phase after the incubation is ethylene glycol. Ethylene glycol accounts for at least $75 \%$ of the radioactivity in the aqueous phase and the amount of ethylene glycol lost to the organic phase is less than $5 \%$ of the total ethylene-glycol. The assay is proportional to microsomal protein up to $200 \mu \mathrm{g}$ per $0.5 \mathrm{ml}$ assay and is proportional to incubation time up to $15 \mathrm{~min}$ (Fig. 1). If microsomes prepared by $\mathrm{CaCl}_{2}$ precipitation rather than ultracentrifugation are used, the glycol-ether monooxygenase specific activity is only about $20 \%$ as large but the assay using these microsomes is proportional to microsomal protein up to $700 \mu \mathrm{g}$ protein per $0.5 \mathrm{ml}$ assay. Glycol-ether monooxygenase in microsomes prepared by $\mathrm{CaCl}_{2}$ precipitation has an apparent $K_{\mathrm{m}}$ for 6-methyltetrahydropterin that is 5-fold lower and an apparent $V_{\max }$ that is about 10-13-fold lower than that found with microsomes prepared by ultracentrifugation (Fig. 3).

\section{TABLE I}

Identification of ethylene glycol as reaction product

The glycol-ether monooxygenase reaction was performed as described in the legend to Fig. 1, except that the incubation period was $30 \mathrm{~min}$ and the microsomal protein concentration was $0.8 \mathrm{mg} / \mathrm{ml}$. Where indicated, 6-methyltetrahydropterin cofactor was absent. The reaction was stopped by extraction [12] of unreacted ether lipid. Either $0.1 \mathrm{ml}$ of the aqueous phase or $0.5 \mathrm{ml}$ of the organic phase, as indicated, was mixed with $2.5 \mathrm{nmol}$ of ethylene glycol, streaked on thin layers of boric acid-impregnated silica gel [17], and developed with the indicated solvent [18]. Solvent A was $n$-butanol/water $(9: 1)$ and solvent B was chloroform/acetone $/ 5 \mathrm{M}$ aqueous ammonia $(1: 8: 1)$. Ethylene glycol was visualized in standard lanes of the chromatogram by spraying with periodate-benzidine spray reagent [19], and the indicated regions were scraped from the chromatogram and counted. Radioactivity recovered from these regions of the chromatogram accounted for $83-98 \%$ of the activity chromatographed.

\begin{tabular}{|c|c|c|c|c|c|}
\hline \multirow[t]{2}{*}{$\begin{array}{l}\text { Extract } \\
\text { phase }\end{array}$} & \multirow[t]{2}{*}{$\begin{array}{l}\text { TLC } \\
\text { solvent }\end{array}$} & \multirow[t]{2}{*}{$\begin{array}{l}\text { Reaction } \\
\text { condition }\end{array}$} & \multicolumn{3}{|c|}{$\begin{array}{l}\text { Activity in chromatogram } \\
\text { region (cpm) }\end{array}$} \\
\hline & & & origin & glycol & rest \\
\hline \multirow[t]{2}{*}{ Aqueous } & A & - cofactor & 17 & 0 & 6 \\
\hline & & + cofactor & 27 & 710 & 112 \\
\hline \multirow[t]{2}{*}{ Aqueous } & B & - cofactor & 103 & 46 & 30 \\
\hline & & + cofactor & 50 & 743 & 92 \\
\hline \multirow[t]{2}{*}{ Organic } & B & - cofactor & 24 & 58 & 6343 \\
\hline & & + cofactor & 25 & 301 & 1782 \\
\hline
\end{tabular}




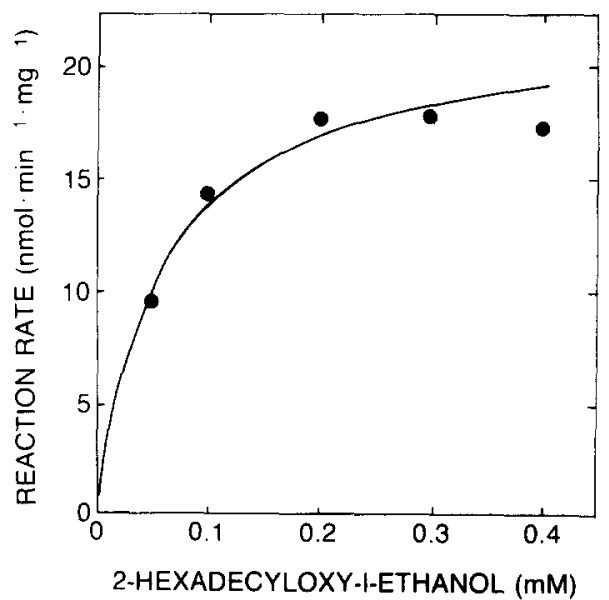

Fig. 2. Dependence of glycol-ether monooxygenase assay on the concentration of 2-hexadecyloxyethan-1-ol. Assay conditions were as described in the legend to Fig. 1. The incubation time was $15 \mathrm{~min}$ and the microsomal protein concentration (prepared by ultracentrifugation) was $0.2 \mathrm{mg} / \mathrm{ml}$. The curve depicts the Michaelis-Menten equation for $K_{\mathrm{m}}=0.06 \mathrm{mM}$ and $V_{\max }=22 \mathrm{nmol} / \mathrm{min}$ per $\mathrm{mg}$.

\section{Spectrophotometric assay}

This assay uses a modification of an assay method for phenylalanine hydroxylase (L-phenylalanine, tetrahydrobiopterin: oxygen oxidoreductase (4-hydroxylating), EC 1.14.16.1) [20], the basis of the assay is illustrated in Fig. 4. Dihydropteridine reductase is used to couple NADH oxidation to tetrahydropterin oxidation. The reaction mixture was similar to that used for the radiometric assay except that glutathione was omitted, and $0.15 \mathrm{mM}$ NADH and an excess of dihydropteridine reductase were added. Before use, dihydropteridine reductase was dialyzed overnight against 1000 vol. of $10 \mathrm{mM}$ Tris- $\mathrm{HCl}\left(\mathrm{pH} \mathrm{8.0)}\right.$ at $4^{\circ} \mathrm{C}$ in order to remove its glycerol-containing solvent. The reaction

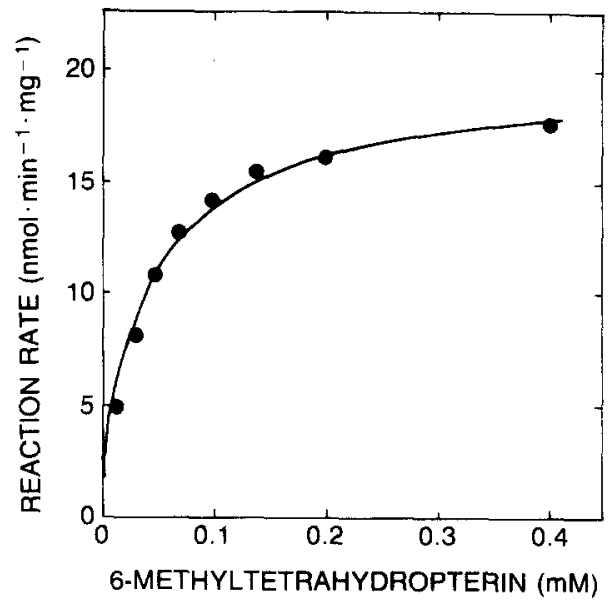

Fig. 3. Dependence of glycol-ether monooxygenase assay on the concentration of 6-methyltetrahydropterin. Assay conditions were as described in the legend to Fig. 1. The incubation time was $15 \mathrm{~min}$ and the microsomal protein concentration was $0.2 \mathrm{mg} / \mathrm{ml}$. The curve depicts the Michaelis-Menten equation for $K_{\mathrm{m}}=0.041 \mathrm{mM}$ and $V_{\max }=19.6 \mathrm{nmol} / \mathrm{min}$ per $\mathrm{mg}$.

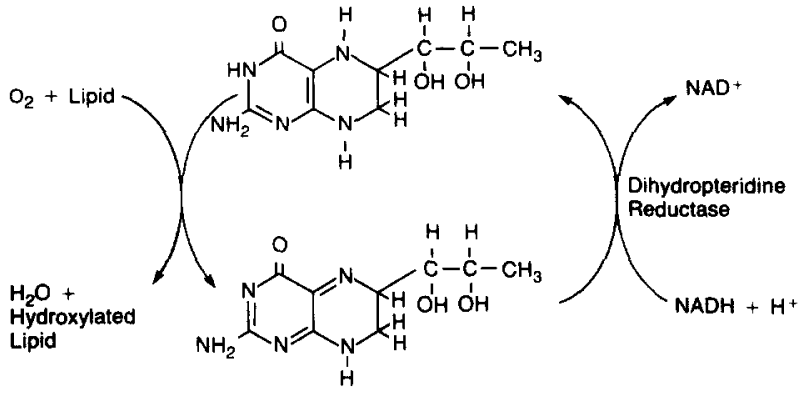

Fig. 4. Tetrahydropteridine-dependent oxidation of ether lipids.

mixture was incubated for $5 \mathrm{~min}$ at room temperature without ether lipid, then the ether lipid was added and the absorbance at $340 \mathrm{~nm}$ followed for $10 \mathrm{~min}$. A reaction mixture lacking ether lipid was used as a control for NADH oxidation not due to glycol-ether monooxygenase. To determine the amount of dihydropteridine reductase required, the rate of spectrophotometric assay was measured at several concentrations of reductase. The amount of reductase chosen was enough so that additional reductase did not further increase the rate of the spectrophotometric assay. The activity of dihydropteridine reductase required for the spectrophotometric assay was found to be 0.2 and $0.5 \mu \mathrm{mol} / \mathrm{min}$ reductase activity per $\mathrm{ml}$ for 5-methyltetrahydropterin and 6,7-dimethyltetrahydropterin, respectively. Dependence of this spectrophotometric assay upon substrates is shown in Fig. 5. The undulation in some of the tracings was probably caused by the presence of the microsomes.

\section{Radiometric method of alkyl glycerol monooxygenase as-} say

Alkyl glycerol monooxygenase was assayed radiometrically following a method similar to that described for alkyl glycerol monooxygenase. Instead of alkyl glycerol 1- $O$-hexadecyl-rac- $\left[2-{ }^{3} \mathrm{H}\right]$ glycerol (spec. act. 475 $\mathrm{cpm} / \mathrm{nmol})$ in ethanol $(20 \mu \mathrm{l})$ was added to the incubation mixture and the radioactivity in the product ([2${ }^{3} \mathrm{H}$ ]glycerol) was determined by the same solvent partition method.

\section{Dihydropteridine reductase assay}

The assay is a modification of the method of Craine et al. [21]. The buffer was either $50 \mathrm{mM}$ Tris- $\mathrm{HCl}(\mathrm{pH}$ $7.5)$ or $100 \mathrm{mM}$ potassium glycine $(\mathrm{pH} 8.8)$ depending upon the buffer used for the glycol-ether monooxygenase assay. The tetrahydropterin used was either $10 \mu \mathrm{M}$ 6-methyltetrahydropterin or 6,7-dimethyltetrahydropterin, as appropriate.

\section{Miscellaneous methods}

The concentrations of the tetrahydropterin solutions were assayed by absorbance at $266 \mathrm{~nm}$ in $0.1 \mathrm{M} \mathrm{HCl}$ [22] and by their spectra [23]. Microsomal protein was 


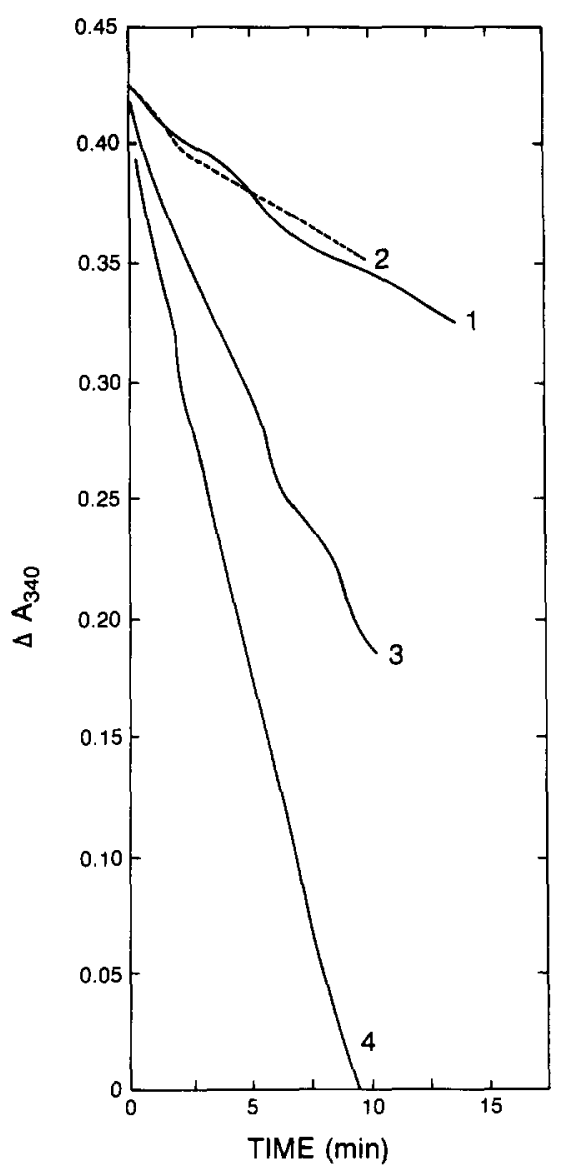

Fig. 5. Substrate-dependence of the spectrophotometric assay of glycol-ether monooxygenase. The complete reaction mixture (curve 4) consisted of the following components: $100 \mathrm{mM}$ potassium glycine (pH 8.8), $0.5 \mathrm{mM}$ 2-hexadecyloxyethan-1-ol, $0.2 \mathrm{mM}$ 6-methyltetrahydropterin, $5 \mathrm{mM}$ ammonium sulfate, $0.15 \mathrm{mM} \mathrm{NADH}, 0.2 \mu \mathrm{mol} / \mathrm{min}$ dihydropteridine reductase activity per $\mathrm{ml}, 100 \mu \mathrm{mol} / \mathrm{min}$ catalase activity per $\mathrm{ml}$, and $0.2 \mathrm{mg}$ microsomal protein per $\mathrm{ml}$. The mixture was preincubated for $5 \mathrm{~min}$ at $25^{\circ} \mathrm{C}$ in the absence of both 6-methyltetrahydropterin and 2-hexadecyloxy-ethan-1-ol, then the following additions were made and the $A_{340}$ recorded: no additions (curve 1 ), 2-hexadecyloxyethan-1-ol (curve 2), 6-methyltetrahydropterin (curve 3 ), and both 6-methyltetrahydropterin and 2-hexadecyloxyethan-1-ol (curve 4).

measured by the method of Peterson [24] using bovine serum albumin as the standard.

\section{Results}

Dependence of alkyl glycol monooxygenase on different cofactors is presented in Table II. The data clearly show that the enzyme has an absolute requirement for 6-methyltetrahydropterin and that its activity is stimulated by catalase and $\mathrm{NH}_{4}^{+}$but not by glutathione.

To confirm that the $O$-alkyl glycol-ether monooxygenase is specific for tetrahydropterins, several different non-pterin reducing agents were tried as alternative cofactors. No glycol-ether monooxygenase activity could be detected with any of the following reducing
TABLE II

Cofactor requirements of alkyl glycol monooxygenase

The incubation mixture (whole system) contained potassium glycine buffer $(100 \mathrm{mM}, \mathrm{pH} 8.8)$, disodium glutathione $(10 \mathrm{mM}),\left(\mathrm{NH}_{4}\right)_{2} \mathrm{SO}_{4}$ $(5 \mathrm{mM})$, catalase $(500 \mathrm{U})$, 6-methyltetrahydropterin $(0.2 \mathrm{mM}), 2$ hexadecyloxy $\left[1-{ }^{3} \mathrm{H}\right]$ ethan-1-ol $(0.23 \mathrm{mM}$, specific activity $=475$ $\mathrm{cpm} / \mathrm{nmol}$ ) and $0.1 \mathrm{mg}$ microsomal protein in the final incubation volumes of $0.5 \mathrm{ml}$. The mixtures were incubated at $37^{\circ} \mathrm{C}$ for $15 \mathrm{~min}$ and the $\left[1-{ }^{3} \mathrm{H}\right]$ ethylene glycol formed was measured after solvent partition as described in the text. Results are the average of duplicate experiments.

\begin{tabular}{ll}
\hline Experiment conditions & $\begin{array}{l}{\left[1-{ }^{3} \mathrm{H}\right] \text { ethylene glycol formed }} \\
\text { (nmol/min per mg protein) }\end{array}$ \\
\hline Whole system & 20.4 \\
Whole system, minus GSH & 24.9 \\
$\begin{array}{l}\text { Whole system, minus } \\
\text { 6-methyltetrahydropterin }\end{array}$ & 0.0 \\
$\begin{array}{l}\text { Whole system, minus }\left(\mathrm{NH}_{4}\right)_{2} \mathrm{SO}_{4} \\
\text { Whole system, minus catalase }\end{array}$ & 13.9 \\
\hline
\end{tabular}

agents: $50 \mu \mathrm{M}$ NADPH (glycol-ether monooxygenase activity was less than $0.05 \mathrm{nmol} / \mathrm{min}$ per $\mathrm{mg}) ; 10 \mathrm{mM}$ glutathione, $1 \mathrm{mM}$ NADH or $1 \mathrm{mM}$ NADPH $(<0.2$ $\mathrm{nmol} / \mathrm{min}$ per $\mathrm{mg}$ ); and $1 \mathrm{mM}$ reduced dichlorophenolindophenol in the presence of glutathione $(<2$ $\mathrm{nmol} / \mathrm{min}$ per $\mathrm{mg}$ ).

In contrast, every tetrahydropterin derivative tested had cofactor activity with the glycol-ether monooxygenase (Table III), but the enzyme was able to discriminate among the tetrahydropterins in terms of the kinetic parameters, $K_{\mathrm{m}}$ and $V_{\max }$. $K_{\mathrm{m}}$ for the tetrahydropterin appears to be dependent on both the size of the substituent at position 6 (higher $K_{\mathrm{m}}$ for tetrahydrofolate) and the presence of a substituent at position 7 (higher $K_{\mathrm{m}}$ for 6,7-dimethyltetrahydropterin). The reaction rate at saturating tetrahydropterin appears to be

\section{TABLE III}

Tetrahydropterin specificity of glycol-ether monooxygenase

Assay conditions were as described in the legend to Fig. 1 except that eight different concentrations of the indicated tetrahydropterin were used. The incubation time was $15 \mathrm{~min}$ and the microsomal protein concentration was $0.2 \mathrm{mg} / \mathrm{ml}$. Kinetic parameters were calculated by a least-squares method [25].

\begin{tabular}{lccl}
\hline $\begin{array}{l}\text { Tetrahydropterin } \\
\text { substrate }\end{array}$ & $\begin{array}{l}\text { Apparent } K_{\mathrm{m}} \\
(\mu \mathrm{M})\end{array}$ & $\begin{array}{l}\text { Apparent } V_{\max } \\
(\mathrm{nmol} / \mathrm{min} \text { per mg) }\end{array}$ & $V_{\max } / K_{\mathrm{m}}$ \\
\hline Pterin & $60 \pm 33$ & $6.0 \pm 1.8$ & 0.10 \\
6-Methylpterin & $41 \pm 2.0$ & $19.6 \pm 0.32$ & 0.48 \\
Biopterin & $42 \pm 4.6$ & $18.3 \pm 0.68$ & 0.44 \\
Folic Acid & $600 \pm 140$ & $5.8 \pm 0.65$ & 0.01 \\
6,7-Dimethylpterin & $150 \pm 8.3$ & $2.0 \pm 1.1$ & 0.13 \\
\hline
\end{tabular}


TABLE IV

Ratio of tetrahydropterin oxidized to glycol ether cleaved

Microsomal protein $\left(0.2 \mathrm{mg}\right.$ ) was incubated for $5 \mathrm{~min}$ at $25^{\circ} \mathrm{C}$ in $1 \mathrm{ml}$ of the following reaction mixture: $100 \mathrm{mM}$ potassium glycine (pH 8.8 ), the indicated tetrahydropterin derivative at several concentrations, $5 \mathrm{mM}$ ammonium sulfate, $0.15 \mathrm{mM} \mathrm{NADH}, 1000 \mu \mathrm{mol} / \mathrm{min}$ catalase activity per $\mathrm{ml}$ and dihydropteridine reductase $(0.2$ and $0.5 \mu \mathrm{mol} / \mathrm{min}$ per $\mathrm{ml}$ for 6-methyltetrahydropterin and 6,7-dimethyltetrahydropterin, respectively). The reaction mixture was then made $0.4 \mathrm{mM}$ in 2-hexadecyloxy $\left[1-{ }^{3} \mathrm{H}\right]$ ethan-1-ol and the mixture incubated 10 min more at $25^{\circ} \mathrm{C}$ during which time the decrease in $A_{340}$ was measured. The amount of $\left[{ }^{3} \mathrm{H}\right]$ ethylene glycol formed at the end of the reaction was also determined. Blank reaction mixtures either lacked 2-hexadecyloxy-ethan-1-ol or used boiled microsomal protein. Kinetic parameters were calculated by the method of Wilkinson [25].

\begin{tabular}{|c|c|c|c|c|}
\hline Tetrahydropterin & Coupling ratio & Assay method & $\begin{array}{l}\text { Apparent } K_{\mathrm{m}} \\
(\mu \mathrm{M})\end{array}$ & $\begin{array}{l}\text { Apparent } V_{\max } \\
\text { (nmol/min per mg) }\end{array}$ \\
\hline 6-Methyltetrahydropterin & $1.3 \pm 0.086($ S.D., $\mathrm{n}=7)$ & $\begin{array}{l}\text { spectrophotometric } \\
\text { radiometric }\end{array}$ & $\begin{array}{l}60 \pm 15 \\
52 \pm 5.7\end{array}$ & $\begin{array}{ll}30 & \pm 2.6 \\
21 & \pm 1.0\end{array}$ \\
\hline 6,7-Dimethyltetrahydropterin & $1.1 \pm 0.23($ S.D.,$n=6)$ & $\begin{array}{l}\text { spectrophotometric } \\
\text { radiometric }\end{array}$ & $\begin{array}{l}120 \pm 12 \\
82 \pm 8.2\end{array}$ & $\begin{array}{l}21.5 \pm 0.95 \\
16.0 \pm 0.6\end{array}$ \\
\hline
\end{tabular}

dependent on the presence of a small substituent at position 6 (lower $V_{\max }$ with tetrahydrofolate and tetrahydropterin). These structural relationships can be seen clearly by the values for $V_{\max } / K_{\mathrm{m}}$ which are shown in the last column. As can be seen, according to this ratio, tetrahydrohydrobiopterin and 6-methyltetrahydropterin are significantly better cofactors than any of the other tetrahydropterins. With every tetrahydropterin, the relationship between initial velocity and increasing concentrations of the tetrahydropterin was hyperbolic.

The only non-tetrahydropterin which was found to support the glycol-ether monooxygenase reaction was 2,4,5-triamino-6-hydroxypyrimidine. With this substance a reaction rate was observed which was about 24 nmol per h per $3.9 \mathrm{mg}$ of microsomal protein (blank reaction used heat-denatured microsomes). That 2,4,5triamino-6-hydroxypyrimidine can bind to the glycol-

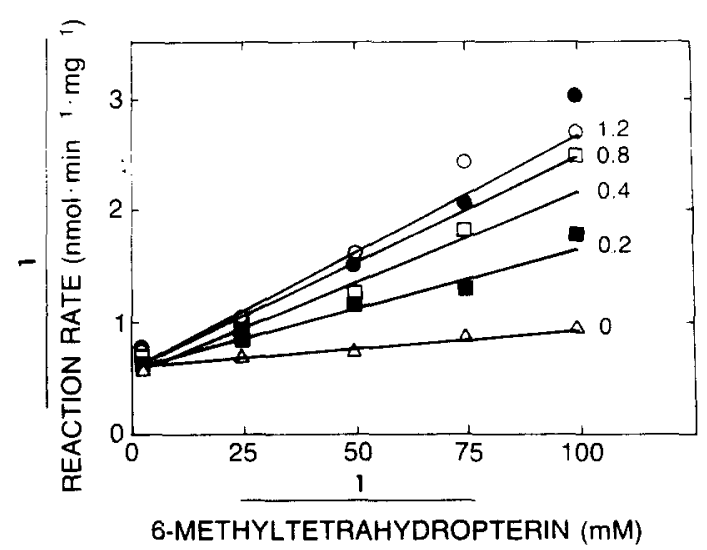

Fig. 6. Inhibition of glycol-ether monooxygenase reaction by 2,4,5-triamino-6-hydroxypyrimidine. Assay conditions were as described in the legend to Fig. 1. The incubation time was $15 \mathrm{~min}$, the microsomal protein concentration was $2.5 \mathrm{mg} / \mathrm{ml}$ and the concentration of $6-$ methyltetrahydropterin as indicated. The concentrations of inhibitor

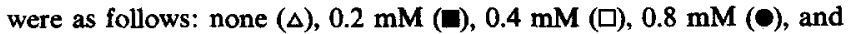
$1.2 \mathrm{mM}(\mathrm{O})$. Microsomes were prepared by the $\mathrm{CaCl}_{2}$ precipitation method (16). The lines depict double reciprocal plots that are best fits [25] to the Michaelis-Menten equation. ether monooxygenase is demonstrated in Fig. 6. This pyrimidine derivative is a competitive inhibitor with respect to 6-methyltetrahydropterin. Fit of the data to the equation for linear competitive inhibition by Cleland's least-squares method [26] indicates that $K_{\mathrm{I}}=0.24$ $\mathrm{mM}$. 2,4,5-Triamino-6-hydroxypyrimidine has previously been found to be a substrate for the classic tetrahydropterin-dependent hydroxylase, phenylalanine hydroxylase $[27,28]$.

Two other tetrahydropterin-dependent hydroxylases, phenylalanine hydroxylase (EC 1.14.16.1) and tyrosine hydroxylase (L-tyrosine, tetrahydropteridine : oxygen oxidoreductase (3-hydroxylating), EC 1.14.16.2), have been found to catalyze oxidation of tetrahydropterin that is dependent on the amino acid substrate but which does not lead to amino acid hydroxylation [29]. Significant uncoupling was not observed with the glycol-ether monooxygenase when the tetrahydropterin cofactor was either 6-methyltetrahydropterin or 6,7-dimethyltetrahydropterin (Table IV). With either of these tetrahydropterins, the stoichiometry, is about 1 tetrahydropterin oxidized per 2 hexadecyloxy-ethan-1-ol hydroxylated. There may be uncoupling when the cofactor is 2,4,5-triamino-6-hydroxypyrimidine since the reaction rate by the spectrophotometric assay was about 0.5 to 1.8 $\mathrm{nmol} / \mathrm{min}$ per $\mathrm{mg}$, but only about $0.1 \mathrm{nmol} / \mathrm{min}$ per $\mathrm{mg}$ by the radiometric assay. Further examination of the effect of tetrahydropterin structure on stoichiometry must await partial purification of the glycol-ether monooxygenase since the spectrophotometric assay has a large nonspecific NADH oxidation when microsomes are used as the source of the enzyme.

To test whether cytochrome P-450-dependent hydroxylase is involved in the glycol-ether monooxygenase reaction, the effect of carbon monoxide [30] was measured (Table V). Carbon monoxide inhibited a cytochrome $P$-450-dependent hydroxylase ether cleavage reaction, 7-ethoxycoumarin de-ethylase, by $60-70 \%$ but had no effect on the glycol-ether monooxygenase. Fur- 


\section{TABLE V}

Failure of carbon monoxide to inhibit the glycol-ether monooxygenase

The following mixtures were stirred for $2.5 \mathrm{~min}$ under the indicated atmosphere: $100 \mathrm{mM}$ Tris- $\mathrm{HCl}(\mathrm{pH} 7.6), 10 \mathrm{mM}$ disodium glutathione, $5 \mathrm{mM}$ ammonium sulfate, $0.05 \mathrm{mM}$ NADPH, $0.2 \mathrm{mM}$ 6-methyltetrahydropterin, $5 \mathrm{mM}$ glucose 6-phosphate, $8.2 \mu \mathrm{mol} / \mathrm{min}$, glucose6-phosphate dehydrogenase activity per $\mathrm{ml}, 1000 \mu \mathrm{mol} / \mathrm{min}$ catalase activity per $\mathrm{ml}$ and microsomes. Tubes containing the reaction mixtures were then immediately capped, additional NADPH and the appropriate substrate injected, the tube recapped and the reaction rate measured. Glycol-ether monooxygenase activity was assayed by the radiometric assay and cytochrome $P$-450-dependent hydroxylase was assayed by a fluorometric method based on the de-ethylation of 7-ethoxycoumarin [31]. It should be noted that the microsomes used in the first experiment were prepared by ultracentrifugation whereas those used in the second experiment were prepared by aggregation with $\mathrm{CaCl}_{2}$ [16].

\begin{tabular}{lll}
\hline $\begin{array}{l}\text { Reaction } \\
\text { atmosphere }\end{array}$ & \multicolumn{2}{l}{ Enzyme activity (nmol/min per mg) } \\
\cline { 2 - 3 } & $\begin{array}{l}\text { glycol-ether mono- } \\
\text { oxygenase }\end{array}$ & $\begin{array}{l}\text { cytochrome P-450- } \\
\text { dependent hydroxylase }\end{array}$ \\
\hline Air & 12.4 & 0.076 \\
$\mathrm{CO}: \mathrm{O}_{2}(4: 1)$ & 11.8 & 0.029 \\
$\mathrm{~N}_{2}: \mathrm{O}_{2}(8: 1)$ & 1.2 & 0.174 \\
$\mathrm{CO}: \mathrm{O}_{2}$ & 1.2 & 0.057 \\
\hline
\end{tabular}

ther evidence that the glycol-ether monooxygenase is distinct from cytochrome $P-450$ hydroxylase is the observation that 6-methyltetrahydropterin will not support the 7-ethoxycoumarin de-ethylase reaction.

To investigate the question of whether alkyl glycerol competes for the same enzyme or not, we performed inhibition experiments in which increasing concentrations of chimyl alcohol were added to the incubation mixture. As seen in Table VI, there was a proportionate inhibition of the oxidation of hexadecyl glycol with the increasing concentration of chimyl alcohol. The nature of this inhibition was studied further by varying the

\section{TABLE VI}

Effects of chimyl alcohol on alkyl glycol monooxygenase

The whole system is the same as described in Table $\mathrm{V}$ except that the amount of ethanol in the incubation mixtures was $40 \mu 1$ instead of 20 $\mu 1$. The chimyl alcohol and $1-O$-hexadecyl[ $\left[2-{ }^{3} \mathrm{H}\right]$ ethylene glycol were added as ethanolic solutions to the incubation mixture as described in the text. Results are the average of two experiments which varied within $\pm 5 \%$ from the average.

\begin{tabular}{ll}
\hline Experiment conditions & $\begin{array}{l}{\left[1-{ }^{3} \mathrm{H}\right] \text { Ethylene glycol }} \\
\text { formed (nmol/min } \\
\text { per mg protein })\end{array}$ \\
\hline Whole system & 22.7 \\
Whole system + chimyl alcohol $(0.03 \mathrm{mM})$ & 10.1 \\
Whole system + chimyl alcohol $(0.06 \mathrm{mM})$ & 7.0 \\
Whole system + chimyl alcohol $(0.12 \mathrm{mM})$ & 4.4 \\
\hline
\end{tabular}

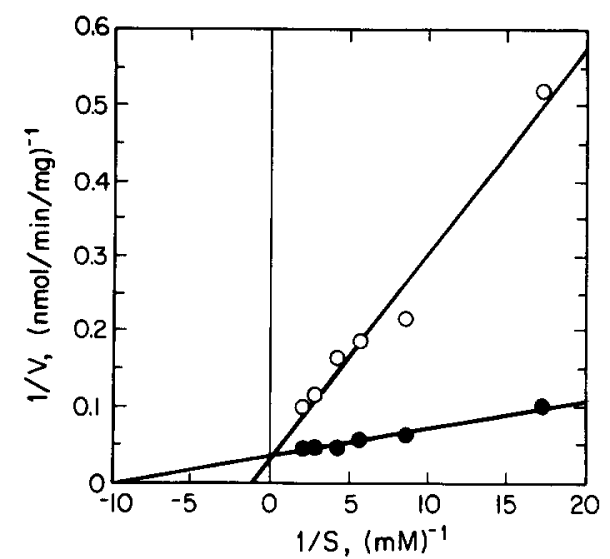

Fig. 7. Effects of chimyl alcohol on the alkyl glycol monooxygenase activity at different concentrations of $1-O$-hexadecyl[ $\left.2-{ }^{3} \mathrm{H}\right]$ ethylene glycol. Assays were done as described in Table $\mathrm{V}$ in the presence $(O)$ or absence $(\bullet)$ of chimyl alcohol $(60 \mu \mathrm{M})$ and the results are presented as double-reciprocal plots.

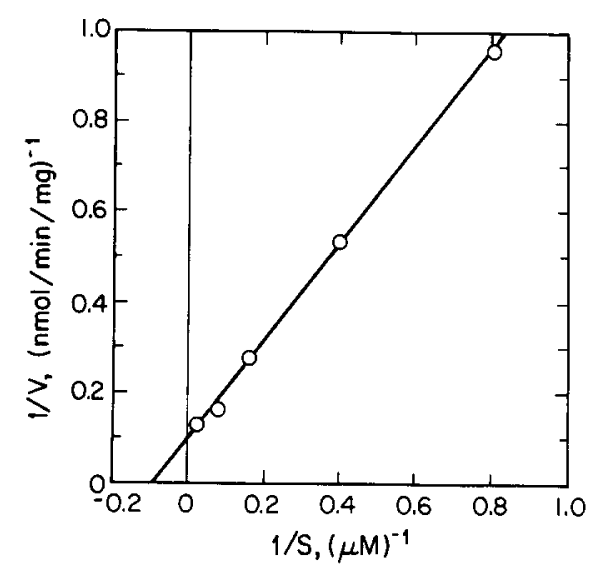

Fig. 8. Activity of alkyl glycerol monooxygenase at different substrate concentrations. The assays using $1-O$-hexadecyl-rac- $\left[2-{ }^{3} \mathrm{H}\right]$ glycerol at different concentrations were done as described in the text.

amounts of hexadecyloxy[ $\left[1-{ }^{3} \mathrm{H}\right]$ ethan-1-ol keeping the chimyl alcohol concentration constant. Results shown in Fig. 7 indicate that the inhibition was competitive in manner, the $K_{\mathrm{m}}$ value of alkyl glycol monooxygenase being increased from 107 to $956 \mu \mathrm{M}$ in the presence of chimyl alcohol, whereas $V_{\max }$ remained the same (30 $\mathrm{nmol} / \mathrm{min}$ per mg protein). From these results, the $K_{\mathrm{i}}$ value for chimyl alcohol was calculated to be $8 \mu \mathrm{M}$. The kinetic constants for chimyl alcohol were separately determined by using radioactive chimyl alcohol (Fig. 8) and the $K_{\mathrm{m}}$ was found to be $12 \mu \mathrm{M}$ and $V_{\max } 11$ $\mathrm{nmol} /$ min per mg protein.

\section{Discussion}

There are three well known tetrahydropterin-dependent hydroxylases: phenylalanine hydroxylase, tyrosine hydroxylase and tryptophan hydroxylase (L-tryptophan, tetrahydropteridine : oxygen oxidoreductase (5-hydroxylating), EC 1.14.16.4) (for review see Ref. 29). The 
experiments reported here support the conclusion that a fourth tetrahydropterin-dependent hydroxylase is an $O$-alkyl glycol-ether monooxygenase. (This enzyme is probably the same as glyceryl-ether monooxygenase (see later)). First, tetrahydropterins or tetrahydropterin analogs (e.g., 2,4,5-triamino-6-hydroxypyrimidine) are the only known electron donors for this reaction. Second, the glycol-ether monooxygenase activity is not an artifact due to tetrahydropterin serving as a reducing agent for cytochrome P-450-dependent hydroxylase. Third, the stoichiometry of the reaction with two different tetrahydropterins is approximately one ether bond cleaved per tetrahydropterin oxidized.

The glycol-ether monooxygenase shows activity with several different tetrahydropterins. Like the aromatic amino acid hydroxylases, however, it functions most effectively with unconjugated tetrahydropterins rather than with conjugated tetrahydropterins, such as tetrahydrofolate. The apparent $K_{\mathrm{m}}$ for the natural, unconjugated tetrahydropterin, tetrahydrobiopterin, is $40 \mu \mathrm{M}$ which is close to the concentration of tetrahydrobiopterin in liver, about $10-15 \mu \mathrm{M}[32,33]$.

The requirements of glycol-ether monooxygenase are the same as described for glycerol-ether monooxygenase except that glutathione did not have any effect (Table II). Glutathione has been reported to stimulate the membrane-bound glycerol-ether monooxygenase [6] but not the solubilized enzyme [34]. Our results showing that chimyl alcohol competitively inhibits the glycerolether monooxygenase (Figs. 7 and 8) and that the inhibition constant $\left(K_{\mathrm{i}}=8 \mathrm{mM}\right.$ ) is very close to the $K_{\mathrm{m}}$ of chimyl alcohol $(12 \mathrm{mM})$ indicate that the same enzyme catalyzes the oxidation of glycol ethers and glycerol ethers.

A number of papers on this subject have been published after most of this work was completed. Koetting et al. $[35,36]$ described a similar spectrophotometric assay for alkyl glycerol-ether monooxygenase where cationic detergents were used to emulsify the substrate. Ishibashi and Imai $[34,37]$ reported solubilization and purification procedures for alkyl glycerol-ether monooxygenase. However, the purified enzyme has very low activity $\left(K_{\text {cat }}=45\right)$ and very high $K_{\mathrm{m}}(660 \mathrm{mM})$ for chimyl alcohol. The specificity of the purified enzyme towards different substrates was not studied.

Because the glycol- and glycerol-ether monooxygenase is a tetrahydropterin-dependent enzyme, it is expected to be affected by disorders of tetrahydropterin metabolism. At least two such genetic diseases, presenting as atypical forms of phenylketonuria, have been found, one in which dihydropteridine reductase activity is absent [38] and another in which the biosynthesis of tetrahydrobiopterin is defective [39]. These diseases are known to disrupt the activity of the tetrahydropterindependent amino acid hydroxylases, and it can be expected that patients with these diseases will show abnormally high concentrations of ether lipids, as well. Since the function of these lipids is not established, further work will be required in order to be able to predict symptoms that might be expected from a disruption of ether lipid degradation.

\section{Acknowledgments}

This work was supported by Project 236, Health Services, DHHS; U.S. Public Health Service Grant HD03110, National Institute of Child Health and $\mathrm{Hu}-$ man Development, NIH; and U.S. Public Health Service Research Grant RR-46, General Clinical Research Centers Branch of the Division of Research Resources, and NIH extramural grant NS 08841.

\section{References}

1 Tietz, A., Lindberg, M. and Kennedy, E.P. (1964) J. Biol. Chem. 239, $4081-4090$.

2 Pfleger, R.C., Piantadosi, C. and Snyder, F. (1967) Biochim. Biophys. Acta 144, 633-648.

3 Snyder, F., Malone, B. and Piantadosi, C. (1973) Biochim. Biophys. Acta 316, 259-265.

4 Lee, T.-C., Blank, M.L., Fitzgerald, V. and Snyder, F. (1981) Arch. Biochem. Biophys. 208, 353-357.

5 Snyder, F., Malone, B. and Piantadosi, C. (1974) Arch. Biochem. Biophys. 161, 402-407.

6 Soodsma, J.F., Piantadosi, C. and Snyder, F. (1972) J. Biol. Chem. 247, 3923-3929.

7 Taylor, D. and Hochstein, P. (1977) Arch. Biochem. Biophys. 179, 456-461.

8 Rembold, H. and Buff, K. (1972) Eur. J. Biochem. 28, 579-585.

9 Baumann, W.J., Schmid, H.H.O., Ulshöfer, H.W. and Mangold, H.K. (1967) Biochim. Biophys. Acta 144, 355-365.

10 Snyder, F., Malone, B. and Blank, M.L. (1970) J. Biol. Chem. 245, 1800-1805.

11 Das, A.K. and Hajra, A.K. (1984) Biochim. Biophys. Acta 796, 178-189.

12 Bligh, E.G. and Dyer, W.J. (1959) Can. J. Biochem. Physiol. 37 , 911-917.

13 Pohland, A., Flynn, E.H., Jones, R.G. and Shive, W. (1951) J. Am Chem. Soc. 73, 3247-3252.

14 Fukushima, T., Kobayashi, K., Eto, I. and Shiota, T. (1978) Anal. Biochem. 89, 71-79.

15 Rock, C.O., Baker, R.E.C., Fitzgerald, V. and Snyder, F. (1976) Biochim. Biophys. Acta 450, 469-473.

16 Schenkman, J.B. and Cinti, D.L. (1978) Methods Enzymol. 52, 83-89.

17 Thomas, III., A.E., Scharoun, J.E. and Ralston, H. (1965) J. Am. Oil Chem. Soc. 42, 789-792.

18 Petrowitz, H.J. (1969) in Thin Layer Chromatography, A Laboratory Handbook (Stahl, E., ed.), p. 662, Springer-Verlag, New York.

19 Krebs, K.G., Heussen, D. and Wimmer, H. (1969) in Thin Layer Chromatography, A Laboratory Handbook (Stahl, E., ed.), p. 885, Springer-Verlag, New York.

20 Kaufman, S. (1957) J. Biol. Chem. 226, 511-524.

21 Craine, J.E., Hall, E.S. and Kaufman, S. (1972) J. Biol. Chem. 247, 6082-6091.

22 Shiman, R., Akino, M. and Kaufman, S. (1971) J. Biol. Chem. 246, $1330-1340$.

23 Viscontini, M. (1971) Methods Enzymol. 18B, 678-705.

24 Peterson, G.L. (1977) Anal. Biochem. 83, 346-356. 
25 Wilkinson, G.N. (1961) Biochem. J. 80, 324-332.

26 Cleland, W.W. (1967) Adv. Enzymol. 29, 1-32.

27 Kaufman, S. (1979) J. Biol. Chem. 254, 5150-5154.

28 Bailey, S.W. and Ayling, J.E. (1978) Biochem. Biophys. Res. Commun. 85, 1614-1621.

29 Kaufman, S. and Fisher, D.B. (1974) in Molecular Mechanisms of Oxygen Activation (Hayaishi, O., ed.), pp. 285-369, Academic Press, New York.

30 Estabrook, R.W., Cooper, D.Y. and Rosenthal, O. (1963) Biochem. Z. 38, 741-755.

31 Prough, R.A., Burke, M.D. and Mayer, R.T. (1978) Methods Enzymol. 52, 372.

32 Baker, H., Frank, O., Bacchi, C.J. and Hutner, S.H. (1974) Am. J. Clin. Nutr. 27, 1247-1253.
33 Fukushima, T. and Nixon, J.C. (1980) Anal. Biochem. 102, 176188.

34 Ishibashi, T. and Imai, Y. (1983) Eur. J. Biochem. 132, 23-27.

35 Koetting, J., Unger, C. and Eibl, H. (1987) Lipids 22, 824-830.

36 Koetting, J., Unger, C. and Eibl, H. (1987) Lipids 22, 831-835.

37 Ishibashi, T. and Imai, Y. (1985) J. Lipid Res. 26, 393-395.

38 Kaufman, S., Holtzman, N.A., Milstien, S., Butler, I.J. and Krumholz, A. (1975) New England J. Med. 293, 786-790.

39 Kaufman, S., Berlow, S., Summer, G.K., Milstien, S., Schulman, J.D., Orloff, S., Spielberg, S. and Pueschel, S. (1978) N. Engl. J. Med. 299, 673-679. 